\title{
THE BANKING DEVELOPMENT WITHIN THE FRAMEWORK OF FINANCIAL GLOBALIZATION
}

\author{
Dino Bruža, Lecturer, PhD student \\ Faculty of Economics Osijek \\ Address: Trg Ljudevita Gaja 7, Osijek \\ E-mail: dino.bruza@gmail.com \\ Luka Latkovich, MSc \\ United Airline U.S.A. \\ Address: 42 Van Wagenen Avenue, apt. 12, Jersey City, NJ \\ E-mail: latkovich.luka@gmail.com
}

\begin{abstract}
The concept of a bank has a long history of origin, but a short history in relation to as it is known today. The first traces of banking can historically be placed at a time when money was deposited with jewelers, but over time, the practice of lending surplus money has evolved, which is why its concept of commerce has changed. The subject of this study and research is the bank, primarily as a joint stock company. It reveals issues of functioning banks and banking, the relationship between the bank and other financial institutions, the financial and banking system, and the role and meaning of non-bank financial intermediaries. The purpose of this paper is to highlight the role and importance of banks in business, and to discover the degree of influence on other institutions. By elaborating on labor issues, it highlights their economic importance in financial globalization. The aim of this paper is to get to know its main tasks for which it was founded and the process of transformation of banking services in the global framework, especially in entrepreneurship. $A$ research hypothesis has been formed: financial globalization affects the rapid development of banking, and reveals the great influence of the banking sector on other institutions. During this research several basic scientific methods were used (compilation method, descriptive method, specification and generalization methods and comparison method). Attention is placed on the comparison of the role and importance of the banking industry in the past and in the modern business world. The emphasis is placed on comparing the role and importance of the banking sector in the past and in the modern business world. The analysis of the development of banking and entrepreneurship forms a quality framework for further research, and gives an added value to the readers in terms of a better understanding of the differences between financial institutions, supported by practical examples of selected global banks in the global market.
\end{abstract}

Keywords: bank; banking system; financial operations; financial globalization; entrepreneurship 


\section{INTRODUCTION}

Globalization has affected every aspect of life, both in the private and business world. Banks and the banking system are not exempt from this process. The bank, from what it was in its beginnings, has long since been transformed, so it can be said that globalization of the banking business started long before the term globalization was used at all. In the last 50 years, under the influence of financial globalization, and especially under the influence of information and communication technology, the banking system has acquired a whole new concept of work and activity. The foundations, goals and purpose of banks remained unchanged, but the way of conducting business has changed significantly. According to many authors, the banks remain the most important financial intermediary institutions to date. S\&P Global Intelligence conducted a survey of the world's most influential and largest banks looking at their total assets. In 2018, 28 of the world's most influential banks were singled out, 11 of them from Europe, 11 from Asia and 6 from North America. In 2019, HSBC stands out as the only European bank with assets in excess of $€$ 2 trillion. Considering their assets, the way of doing business and influence, the question arises as to whether the banks would be so successful if there was no financial globalization, that is, globalization in general, and the emergence of new forms and ways of banking business. For this reason, the paper further analyzes the functioning of banks, makes comparations with the modern way of doing business and reveals the main features of financial globalization and the modern banking system. The second section provides a clear concept of banking, as well as the bank's role in the system. It shows the bank development throughout history and explains the structure of the modern banking system. The third section provides an explanation of the financial institutions and explores the separation of banks from other institutions. The emphasis is placed on virtual stock exchanges. The fourth section covers research on the relationship between non-banking financial intermediaries and financial globalization. In the conclusion, the main hypothesis-related analysis results are presented.

\section{BANK AND BANKING - CONCEPT, ROLES AND IMPORTANCE}

The defining term bank can be said to be a complex system, the economic meaning of which can be seen through three main functions of the bank. Two are primarily management of payments, keeping savings deposit of its clients and distribution of credit. In addition, the bank is a financial intermediary and, as such, performs financial intermediation as well as payment intermediation. This can be compared to the traditional team stand regarding the definition of a bank. The bank is an independent financial organization established as a joint stock company, which operates on the principles of liquidity, security and profitability for profit (Kandžija \& Živko, 2004, 27). In the Croatian banking context, researchers have examined the issues of bank efficiency often in context of specific historic periods marked with privatisation, ownership transfer or regulatory changes (Huljak, 2015, 12). Based on the definitions that will be analyzed, the definition of banking can be outlined. Banking is the term for a business that operates by borrowing money and holding deposits. This is general definition, based on credit, which implies that banking is based on customer debt. 
The goal of economics is to manage costs, and, accordingly, it can be stated that the goal of banking is debt management, since it is based on this debt. It should be noted that the aim of the research in this section is to characterize the bank as an economic entity and to connect the modern bank with its earliest forms. Banking, or such operations typical for the banks, as the name says, over the years has experienced one of numerous transformations, due to which the banking system is finally separated from the financial sector and today exists as an independent unit. Others categorize a bank under the financial institutions, as they actually are. It is important to emphasize that, in practice, a business distinction occurred, but, in essence and in theory, it can be stated that banks are most important, and even according to some authors, the bearers of financial sector development, that is, main among financial institutions. Banking, which is based on the debts of its issuers, that is, on their deposits, follows the course of development of the financial system, while simultaneously bringing innovations regarding the development of banks' operations, especially if one considers the modern electronics business, which has become normal in business today.

The historical point of view, definition, functions and types of banks depend on which research field it originates from. In this case, the definitions and bank history from the economic perspective will be considered. The table 1 lists the banks and countries with their headquarters in last decade. In the top ten biggest banks are five from the U.S.A., which leads to a conclusion that half of the market is covered by American banks.

Table 1. World's biggest banks 2010.

\begin{tabular}{|l|l|l|}
\hline Rank & Bank & Country \\
\hline 1 & Bank of America & U.S.A. \\
\hline 2 & Citigroup & U.S.A. \\
\hline 3 & HSBC Holdings & U.K. \\
\hline 4 & Credit Agricole Group & France \\
\hline 5 & Chase Manhattan & U.S.A. \\
\hline 6 & Industrial \& Commercial Bank of China (ICBC) & China \\
\hline 7 & UBS & Switzerland \\
\hline 8 & Deutsche Banke & Germany \\
\hline 9 & Wells Fargo & U.S.A. \\
\hline 10 & Bank One & U.S.A. \\
\hline
\end{tabular}

Source: Statista, https://www.statista.com/statistics (access date: February 15 2020)

It shows that last decade U.S. was a leader in banking development. It is also indicative that China successed to be in the first six leading countries in the world. On the other hand, for example, in 2019 in EU top ten leading banks are banks from Europe, and it shows that they are not affected by the other banks from other continents. Leading banks in Europe in 2019 are shown on the next graph. 


\section{Graph 1. Leading banks in Europe 2019 (by total assets, and in billion euros)}

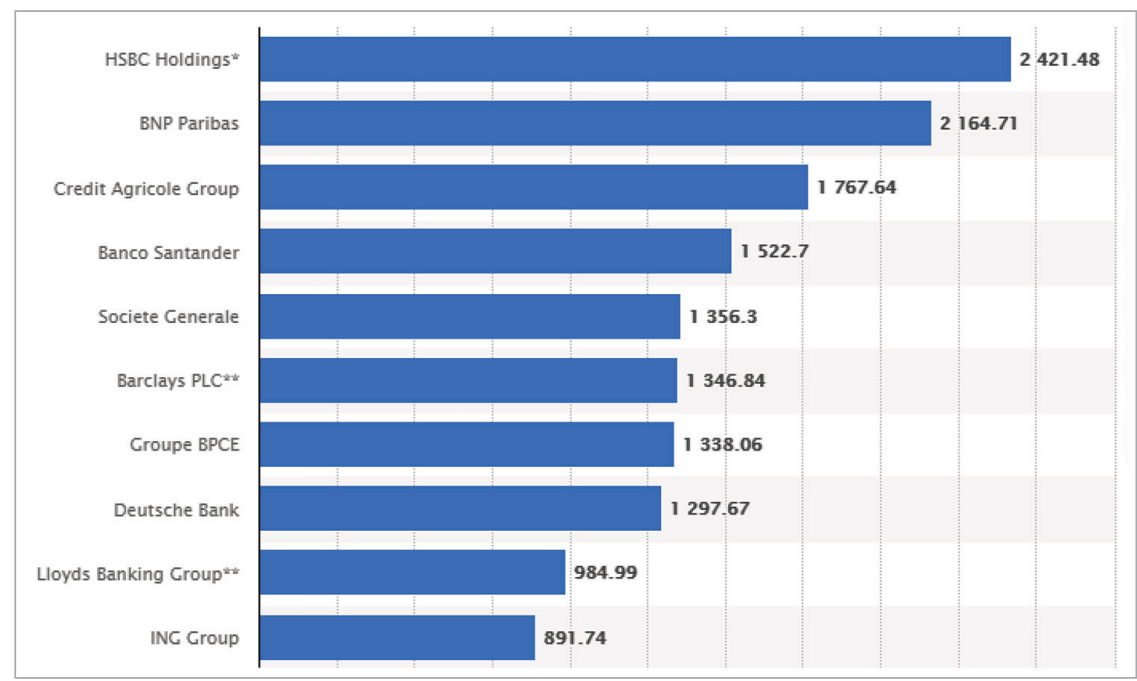

Source: Statista, https://www.statista.com/statistics/383406/leading-europe-banks-by-total-assets/ (access date: February 15 2020)

\subsection{Bank development throughout history}

The banks have experienced a particular transformation throughout history and modern banks differ greatly from the earliest forms of banks. There are several definitions of bank, regarding the perspective (law, economy, etc.). According to Gregurek and Vidaković $(2011,26)$, a bank is an institution that deals with fundraising, placement funds and provision of financial services. They have historically been, and in most countries are still, the most important financial intermediaries (Kandžija \& Živko, 2004, 27). They have their own peculiarities in business, which are regulated by certain laws, regulations and acts. Some authors avoid using the word 'bank' and, instead of the term, use other common names, such as 'a credit institution' or 'financial - corruption institutions'. This makes sense if we take into account the definition given in the introduction. The history of banks dates back to the era when goldsmiths represented and functioned as bankers do today. They were given gold, and would take deposits from wealthy individuals. This developed into a practice in which extra money was lent to those in need, with a particular interest, considering how the reception of the deposit was sufficient only on part of the given money, to meet all current needs. However, the first real banking business appeared within the framework of the slave system, that is, as early as the 7th century A.D. as there is evidence that thesauri existed. 'Thesauri' is the name for a private house, where food was stored for safekeeping, and an additional amount of food was produced, which would then be lent out. Such houses represented the premises that today's society knows by the name of warehouse. The first thesaurus originated in Babylon, and over time, the name was used for officials, and hence the name thesaurus. Furthermore, given that in ancient Greece, foreign exchange jobs developed, the 'trapeze' system was created alongside the foreign exchange jobs. 'Trapeze' is the name for the tables where the exchange work was performed, and the word 'trapeze' in literal translation means 'bench'. The same busi- 
ness was developed by the ancient Romans, but the collapse of the Roman Empire also failed to develop banking in this regard. If it is historically linked to feudalism, when commodity lending reigned, one can see that the emergence of banking has had its ups and downs. Ultimately, in the territory of present-day Italy, more precisely, in the cities of Venice, Florence and Genoa, the first banks were created, that is, in the then context of a payment institution. At that time, the bill of exchange appeared as an instrument of this exchange and payment (Kandžija \& Živko, 2004, 29). The development of banks, and therefore banking, was founded in the 19th century, after which the first joint stock companies appear. The emergence of banks coincides with the Industrial Revolution, a period when investment in the industrial sector is large. In the territory of the former Kingdom of Yugoslavia, state, semi-state and private banks appeared and existed in the 20th century, between the two world wars (Kandžija \& Živko, 2004, 29). The era of the modern banking industry, as it is today, began more specifically in 1882 with the founding of Bank of North America (Mishkin \& Eakins, 2005, 437). In this form the bank moves from America to Europe. Closer to modern times, in the mid-80s and $90 \mathrm{~s}$, the banking industry experienced its first difficult times due to the bankruptcy of various banks, which was caused by mismanagement of their deposits and, thus, deepening their debts. As financial institutions begin to emerge from this crisis, banking companies are grouping together and establishing large global banking systems. That is why it is predicted today that in the future there will be a pair of large banks, which will manage and control the debts and operations of the entire world. Banks experienced their second major crisis just three years ago, when they found themselves in large debt, and because of which they lost confidence in lending to each other, which was normal practice until then. Nowadays, banks are increasingly lending money to other banks, seeking major insurance and are distrustful of the prognosis of entering and exiting new potential recessions. The consolidation of banks at the world level already today results in a decrease in the number of banks, but inversely, an increase in the number of online services, and this trend is expected in the future. Graph 1 shows how the number of banks decreased during the last phase of financial globalization. That doesn't mean they disappeared, they are just transformed into bigger corporations.

\section{Graph 2. Banks in the world over the last thirty years}

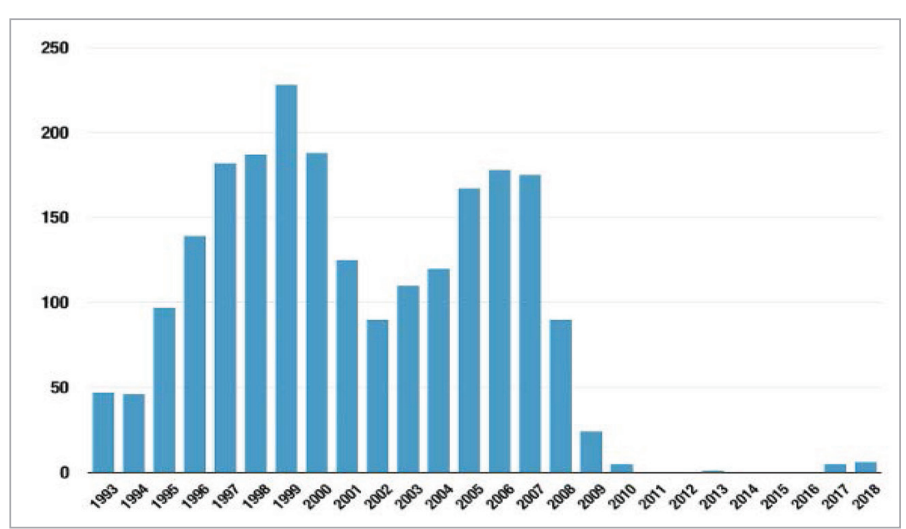

Source: Institute for Local Self-Reliance, https://ilsr.org/number-of-new-banks-created-by-year-1993-to2013/, access date: February 152020. 
What is contradictory is that local banks will not disappear, but are likely to change their functions, in order to preserve their business purpose, to make a profit. With the advent of internet banking, the meaning of bank free zones is diminished, and it is worth remembering that these zones were created at the beginning of financial globalization, in the early 1980s. On the other hand, the future of banks and banking as the world knows it today is questionable, because the typical financial crisis and debt deflation must be compounded by cybercrime, which is causing some banks to endure great losses today, causing the balance sheet to worsen banks, rising interest rates, with the simultaneous weakening of the stock market and the increasing growth of uncertainty, that is, risk, which is becoming one of the characteristics of present and future forms of banking and banking operations in general. Graph 2 gives clear information about bank market share in 2018 when U.S. big banks held more than half of the market. Most popular banks today are Bank of America, JP Morgan Chase, Citigroup and Wells Fargo.

\section{Graph 3. Bank Market share in U.S. in 2018}

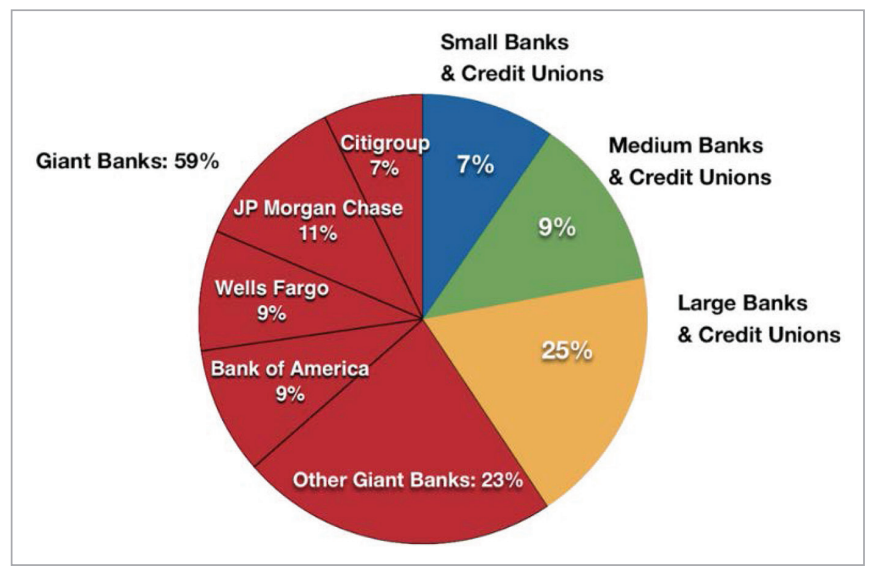

Source: Institute for Local Self-Reliance, https://ilsr.org/number-of-new-banks-created-by-year-1993-to2013/, access date: February 152020.

\subsection{Structural features of modern banking}

Summarizing the history of the emergence and development of a bank as a financial institution, one can also read some of the main features of banking, as a system that exists today. However, in order to extract the essential features of banking, it must be noted that they can be generalized to all types of banks, but also to each individual one. The general division of banks comprises seven types of banks, and the general classification includes a central bank, a commercial or deposit bank, a specialized bank, a universal bank, a mortgage bank, a commercial bank, and finally a savings bank. Each of the above forms of banks has undergone changes in financial instruments, financing techniques and technology, in the emergence of new financial institutions, and in regulation (Kandžija \& Živko, 2004, 36). Also, according to Vinko Kandžija and Igor Živko (2004, 36), "significant characteristics that characterize modern banking can be derived: enlargement, universalization, internationalization, and the application of new technologies in business". Cohe- 
sion is a feature of large banks, which in a globalization context are being merged into world corporations, in order to maximize profits as a business objective. In addition, bank consolidation achieves an increase in profitability, but also an increase in the types of business that banks may not have been able to do, or were prohibited by law from engaging in prior to aggregation. In addition to the merger of traditional banks with other banks, it can be observed that banks also merge with non-banking institutions, which may include insurance companies and securities trading companies.

As mentioned in the previous section, the danger is that the number of banks in the world will decrease, but this is not necessarily a bad thing. Universalization, as another feature, refers to the integration of various types of bank operations into joint operations, reducing various services to several major ones. With the advent of new general-type banks, transactions are also classified under general names. Internationalization is similar to enlargement, except that in this case, the merger is a country-level or state-level bank. The application of new technologies in business is the result of the aforementioned financial globalization, but also the product of the first three characteristics. It has its beginnings in the second half of the last century, which is known to be the period of the technological revolution. Today, there is no bank, or any business entity that has not computerized its business. New technologies have enabled banks to grow their businesses as quickly and as qualitatively as possible, while also meeting the increasing risks of today's climate. In order for banking to continue to function, certain controls on the operations of banks, i.e. banking in general, must be implemented. According to Marta Božina $(2003,3)$, there are three main components that must be controlled in banking. These are: ensuring liquidity, ensuring solvency, and controlling the construction of an efficient financial system in general. Modern banking is far more complex than in recent decades, primarily due to the increasing uncertainty and deepening of the global crisis in recent years. Thus, some emphasize commercial loan theory, switching theory, pooling theory, predicted income theory, fund conversion theory, and many others. The first theory suggests a dilemma between maintaining liquidity and earning money. The second theory indicates a shift from less liquid credit to more liquid money market instruments. The pooling theory is also based on liquidity, in terms of observing all bank sources of funds, while the last two theories are reactions to under-performing liquidity.

\section{FINANCIAL INSTITUTIONS AND THEIR SERVICES}

In recent years, many other financial institutions, such as insurance companies, financial companies, pension funds, mutual funds and investment banks, have grown because of banks (Mishkin, 2010, 8). In the United States, in the late 1980s, it became clear that the Glass - Steagall's law was not fully valid at the time and that there were many loopholes that banks began to use. In 1988, the Supreme Court allowed JPMorgan Bank Holding to subscribe for corporate debt issues and to sign issues of shares in September 1990 (Mishkin, 2010, 269). This turned out to be a big hole in the law, which other bank holding companies started using. Banks are allowed to participate partially in the provision of insurance, but also in part to own real estate. Consequently, nine years later, the law was repealed, and a new one, called the Gramm-Leach-Bliley Act, appeared, which concerned the modernization of financial services. It was also a kind of appeal of the previous 
Glass - Steagall law. Under the new law, states were able to control bank holdings and all activities related to insurance and securities. In the meantime, the consolidation of banks into one large system has been encouraged, all because of the Riegle-Neal law which was enacted in the meantime. As a result, banks have become larger and, consequently, organizationally very complex, and as such financial institutions are engaged in various financial activities. The stock market, as a virtual market, has the characteristics of a traditional one, with the change in the way of doing business, and increasingly focusing on the networking of world stock exchanges. Financial institutions essentially have similar tasks and objectives, but there are some specifics that differentiate between them and there are reasons to diversify these institutions by analysis.

\subsection{Separation of banks from other financial institutions}

Depending on the country, banks gradually began to separate from the financial sector, creating their own banking systems. This logically implies that they have also diversified their services from other financial institutional services that have performed or are just beginning to appear on the market. In this case, an example is provided for Germany, Switzerland, the Netherlands and the United Kingdom. In the first three countries mentioned, a universal banking model emerged, according to which there is no separation of the banking sector from the securities trading industry. In this system, banks provide regulatory banking services, as well as securities and real estate operations and insurance services. The term "development finance institutions" (DFI) encompasses no only government development banks, but also nongovernmental micro-finance organizations, that match grants to attempt to promote community development, decentralization of power, and local empowerment (Yaron \& Schreiner, 2001, 10). In this case, banks were actually allowed to hold large stakes in commercial enterprises, which they rarely do (Mishkin, 2010, 270). In contrast, the U.K. has introduced a so-called British model of universal banking system, which has also been implemented in the British Commonwealth, such as Canada and Australia. In these countries, legally separate subsidiaries are more common, but ownership of shares in commercial companies is not as common as the combination of banks and insurance companies (Mishkin, 2010, 270). Opposite the two systems of separation of banks from other financial institutions is a model characteristic in Japan, where, according to the study, Japanese banks are allowed to hold large stakes in all commercial enterprises, which is not possible in the United States, for example. The Securities Law in Japan states in Article 65 that commercial banks are allowed to participate in the securities business, which is why they partly have the characteristics of U.K. banks. Another difference between the two countries is that in Japan, it is completely illegal to use the structure of a bank holding company in bank operations, while in America it is quite normal and acceptable. Summarizing the abovementioned, we can conclude that banks separated from the financial sector in the mid-1980s. Then the process began very quickly, and is seen in several stages. The first phase of separation was due to the bankruptcy of large banks, while limiting the opening of new ones. The second phase is marked by the information-technological epoch. Many economists believe that separating the banking sector from financial institutions has far greater advantages than disadvantages. That can be supported by the published research by Battilossi and Reis, presented in their book. One advantage might be greater efficiency if the skills required to oversee different 
parts of the financial system are similar (Battilossi \& Reis, 2016, 120). Also, their is another statement of other authors. Financial institutions, as a rule, act as financial intermediaries, and the primary task is to raise funds, and then place them on the financial market. Financial institutions perform a key asset function from parties with surplus funds, suppliers of funds, towards parties with lack of funds, users of funds (Saunders \& Cornett, 2006, 11). It indicates the main purpose of institutions, with clear differences from the main term of bank.

\subsection{Types of financial institutions and their services}

Financial institutions play a key role in channeling funds from surplus parties to surplus parties (Saunders \& Cornett, 2006, 11). As such, they can be classified as financial market intermediaries. The bank is the most important institution in this sector. As a depository financial institution, it provides monetary services and pays interest on collected cash deposits, which are subsequently placed in various loans. In addition to banks, depository institutions are also savings banks, credit services, savings and credit unions and all other institutions that operate with the collection and placement of deposits on the market. There are also various non-depository financial institutions, including pension funds, insurance companies, and special joint venture investors. Anthony Saunders and Marcie Millon Cornett state in their research $(2006,12)$ : "financial institutions are diversifying into commercial banks, savings banks, insurance companies, securities and investment banks, financial companies, mutual funds and pension funds". The functions are divided into types of financial institutions, which are classified in a similar manner, and are divided into commercial banks, institutions similar to banks, insurance companies, investment firms, securities and non-financial corporations. The aforementioned division is very similar to the way in which the types of institutions are classified, according to the division outlined above. It is worthwhile for all institutions to deal with the placement of funds. All institutions, except securities companies, are also engaged in the payment of transactions. Risk, insurance and forward transactions are dealt with by all financial institutions except bank-like institutions. The Commercial Bank, as a depository institution, operates with the aim of lending to the needs of the population and the economy in general. On the one hand, on the asset side, it holds loans, while on the other, on the liabilities side, it holds deposits. The basis for lending is short-term deposits from all sources, and by granting loans, the commercial bank actually increases the money supply in the market. The central link in the system of these banks is the central bank, which controls the establishment of commercial banks, their operation and business, the closure of commercial banks and a number of other provisions. Savings banks, as another type of financial institution, appear in the role of savings deposit associations, which operate similar to commercial banks but with one difference. Namely, they focus their business on one segment, so they are basically specialized financial institutions. Their main task is to collect household savings and market them, be it in the real estate or consumer loans segment. A special type of savings bank is a postal savings bank, which, in addition to these tasks, performs tasks related to cashless payment operations. Insurance companies are financial institutions that offer insurance services, protecting clients from unexpected events, offering insurance such as illness, sudden death, personal injury, fire, theft and other potential hazards. Securities companies perform operations related to the receipt of securities, brokerage, trad- 
ing, and the creation of new markets in which they expand their business. Furthermore, mutual funds are a form of financial institution that deals with the pooling of financial resources and invests in many asset portfolios. Pension funds have the primary role of accumulating the savings of their clients over the years, and these clients subsequently withdraw these amounts upon retirement. Payments to such institutions are exempt from current taxes. The Pension Fund in the Republic of Croatia has played an important role since the independence, but unfortunately, today it is suffering great losses due to the poorly implemented privatization process as well as the conversion process. Financial institutions today have much greater and more uncertain risks in their operations than in the past decades. Today's financial institutions also bear business uncertainty as one of their characteristics, that is, they are marked by an increased degree of various risks. The most significant are credit risk, interest rate risk, market risk, operational risk, currency risk, country risk, liquidity risk, insolvency risk and many others (Šverko, 2002, 640). Every financial institution must pay attention to each of these risks, both in a particular and in a collective way because it happens that the synergies of various types of risks result in great losses and even bankruptcies.

\subsection{Stock market as a virtual financial institution}

The stock market is a pillar of the international economy and is one of the most important drivers of economic growth. The stock market is a segment of the financial market where money and commodities are traded through business operations. The financial system has revolutionized technological advances, especially in terms of e-commerce and virtual trading. This is why part of the research is devoted to a brief overview of the role of the stock market as a virtual financial institution. From 1867, when the teletypewriter was first introduced in the New York Stock Exchange, and, to this day, communication technology has gained huge importance (Bazdan, 2006, 90). In fact, both modern and traditional trading have undergone a transformation in terms of the use of the computer system. In the 21st Century, the major exchanges in the world are New York, London, Tokyo, Sidney, Hong Kong, Singapore, Paris, Frankfurt, Zurich, Geneva, Toronto and Amsterdam, which are interconnected and their business is based on a virtual concept. On March 17, 1994, the Zagreb Stock Exchange quit trading in the traditional way, i.e. it stopped trading on the podium and introduced an electronic stock trading system based on a single trading platform (Bazdan, 2006, 95). From that moment on, the Croatian Stock Exchange has established a system called MOSTich, which has two packages, one based on the provision of key information for ten selected securities and the other package focused on providing information for twenty selected securities, throughout the trading period. All classic stock exchanges have already been withdrawn from the world scene and the benefits of e-commerce worldwide have been accepted in no time. The only downside to the business of these virtual financial institutions is that automated trading eliminates security, that is, clients are no longer anonymous. In addition, with the development of virtual exchanges, cybercrime is on the rise. Because of this phenomenon, the Internet economy has developed. Internal economy is one of the most important aspects of globalization as a worldwide process - it is changing the traditional way of investing and trading (Bazdan, 2006, 96). In the system of diversification of services in the financial markets, information and computer technology prevailed. Electronic commerce is used to the greatest extent in 
the segment of trading, marketing, banking, also called e-banking or telebanking, as well as the computer aviation reservation system and, of course, the stock exchange business. This virtual trading space is a remote business, with all the relevant information on your computer screen that is, working at your desk. There are also numerous changes regarding the relationship of the commissioners, that is, the brokers and their coordinators (Bazdan, 2006, 96). These participants are no longer required to communicate directly, but through the intermediation of a computer network, i.e. via e-mail, thereby connecting the exchanges to virtual computer networks, as explained in the previous section. Concluding consideration and research in this section notices the importance and the great role of virtual stock exchanges in the business world, with the notion that further development of large world centers will be consolidated into one global, thus leading to the end of the phase of financial globalization.

\section{NON-BANKING FINANCIAL INTERMEDIARIES}

The financial market is made up of all the institutions and processes that connect buyers and sellers of financial instruments (Van Horne and Wachowicz, 2002, 22). However, it should not be overlooked that today there are non-banking financial intermediaries as elements of the overall financial market. Financial intervention or intermediation means raising funds from the public by the person or institution and guidance in financial investments, where cash funds collected in the form of cash, selling insurance, paying wagers, deposits into the transactional accounts, etc. (Čečuk, 2002, 77). Financial intermediaries are authorized representatives, who place all stocks, bonds, securities and loans on the financial market. Their role in the entire system of business is based on the purchase of direct claims by one feature or characteristics and the implementation of the transformation process in an indirect way with altered characteristics. This process diversifies risk, secures liquidity, converts many smaller savings deposits into one large loan and ultimately reduces the costs of the financial market. However, these are non-banking financial intermediaries, i.e. non-banking financial institutions, such as savings institutions, insurance companies or companies, pension funds, money market funds, mutual funds and many others. The distinction between banks on the one hand and the capital market and non-banking financial institutions on the other, is not emphasized (Čečuk, $2002,80)$. And the fact remains that under certain conditions the capital market can also be an intermediary, that is, an intermediate or a transformer. This difference does not play a big role when analyzing their functions, which is evident in the analysis made in the previous chapter. The modern theory of financial intermediation, as Andro Čečuk states $(2002,80)$, "is much more explicit in analyzing what banks, as a special kind of intermediary, can do better than the financial market and non-banking financial institutions" and this explains the reason for their existence, emphasizing precisely their advantages.

\subsection{The importance and role of non-banking financial institutions}

The financial system has become more oriented towards the market of capital than banks. It is noted that the role of the bank in all this is slowly declining. According to the aforementioned classical theory of financial intermediation, an indicator of the impor- 
tance of banks is the extent to which they act as intermediaries, i.e. the extent to which depositors deposit money and how banks place these funds in deficit sectors, especially for enterprises (Čečuk, 2002, 90). In contrast, and according to the earlier mentioned modern theory of financial intermediation or mediation, an indicator of the importance of non-banking financial institutions relates to the quality of the services they provide. One of the services relates to the provision of liquidity and the other on monitoring and capital management (Čečuk, 2002, 91). Non-banking financial institutions have increased in number with banks, which is a very important change in the financial system, since this has some implications for the role of banks and their stability in general. The importance of non-banking financial institutions is also reflected in the fact that they have taken on part of the role in collecting savings, which they nevertheless pass on to banks, referred to as loan specialists, whereby Andro Čečuk $(2002,93)$ states that " this trend is not present in the same proportion and in the same intensity in different countries". The strongest such trend is evident in France, compensating for all those changes that, in the past, caused the decline in the number of banks across the country. In addition to the process of mediation, the process which follows is also important. This process is opposite to the previous one and with much stronger implications, that is, with much larger differences in finality. It is about disintermediation. Disintermediation is the process of moving funds from indirect to direct and indirect markets, thus eliminating the intermediary role of financial institutions and the end-to-end receipts operating directly (Čečuk, 2002, 78). The results of such a process are reflected in the fact that the share of assets held by banks has actually declined relative to non-banking financial institutions, while in absolute terms financial assets are on the increase, as there is a growing diversion of directly held assets to non-banking financial institutions. This also indicates that it preserves the process of disintermediation and, in the end, changes the activity of banks and banking in general. Research shows that the traditional deposit and credit activity of a banks role has actually been re-routed to jobs that are based on commission. Non-banking financial institutions, such as life and property insurance institutions, retirement funds and mutual funds, and a number of other mutually competitive institutions, have become very important as institutional investors. This implies an increase in the business of increasing the accumulated cash capital, that is, its mobilization and in lending activity. As a result, they have taken over much of the current banking market. The issue of securities is gradually developing into forms of direct financing. In the last century, after the Great Crisis, banks began to perform all banking operations, but in the short term, they took over other financial activities. Therefore, modern banks can be characterized as universal, that is, multifunctional financial institutions. The reason for that were strict legal regulations, due to which the banks were at a disadvantage compared to other non-bank financial intermediaries. By separating their historical development from that time to the present, it can be concluded that the banks actually wanted to fully meet the needs of their clients, that is, they wanted to merge the entire financial market with the banking market, which would actually stimulate the process of reducing non-banking financial institutions and intermediaries. Of course, this did not happen. But because of these attempts, the world fell into a financial crisis ten years ago. 


\subsection{The impact of financial globalization on non-banking financial intermediaries}

Globalization, as the main process and driver for all the changes the world has experienced in all walks of life, has influenced the financial system, that is, financial institutions, including banking and non-banking, during the 1990s. On the one hand, financial globalization has stimulated the development of multinational companies, increasing the propensity to invest, various business operations of financial institutions, holding companies, and mixing or entering banks into non-banking operations, and vice versa. On the other hand, it has also led to the incredible expansion of stock exchange transactions, especially since the development the virtual stock market. In general, financial globalization has led to the expansion of financial markets and instruments (Čečuk, 2002, 263). However, globalization has also reduced the importance of the actual geographical distance as a factor in establishing and maintaining various relations, among which Andro Čečuk cites economic, political, socio-cultural and many others $(2002,263)$, "while increasing the importance of the financial sphere, meant a rapid development, which is why there has been an expansion of various forms of risk and the emergence of turbulence in today's business". Following the analysis of the two main opposing points of view, financial globalization can be defined by a complex set of a number of processes and sub-processes that are correlated with one another, but which at the same time form a special independent sphere in the entire global system. Financial globalization may include internationalization, universalization, intermediation, disintermediation, integration of institutions with increasing liberalization and, ultimately, financial innovations that have contributed to reducing the financial system operating costs. All the above processes are explained gradually through solving research problems. However, it must be repeated that financial transactions have become global, as is the impact of disintermediation. The securities market has also assumed a global form, as Andro Čečuk states $(2002,264)$ "follows the process of securitization". The consequence of this financial globalization is reflected in the fact that the role of banks has ultimately diminished, with simultaneous structural changes within non-banking intermediary financial institutions. Stock exchanges began the integration process, further modifying the world of finance. Non-banking financial institutions, i.e. non-banking financial intermediaries, under the influence of financial globalization, are promoting new forms of financial instruments in the market. It is characteristic of the simultaneous reduction of those specific systemic risks at lower levels and the expansion or diversification of the overall risk globally. In the new conditions of financial globalization, new instruments and their modification are emerging. What is most important in this context is the development of financial liberalization. Financial liberalization, especially through the liberalization of FDI and portfolio investment, as well as the liberalization of capital flows, can jeopardize the stability of the banking system and increase systemic risk (Čečuk, 2002, 268). Liberalized capital flows, i.e. financial transactions and business activities of non-banking financial intermediaries in the financial market, enable economic development and better allocation of financial resources. Non-bank financial intermediaries are certainly carriers of financial globalization, in accordance with modern business principles and rules. 


\section{CONCLUSION}

The purpose of this work has been fulfilled. The importance of the notion, role and importance of the bank and banking in general was emphasized, and, in addition, the elaboration of the problem highlighted the degree of influence of banks on other financial institutions. In addition, the importance and role of non-banking financial intermediaries and the transformation of financial institutions in the financial market were highlighted, and a comparison of their roles and operations in the past and present has been made. By analyzing the views on history, function, types of banks, financial institutions, and the structure of globalization processes, etc., the conclusion is that there are relatively homogeneous definitions and points of view.

The subject is the historical development of the banks, and the aim of the paper is to get to know its main features and the process of transformation of banking in global terms. This is especially important because the topic of this research is current, even more so because in the last ten years the world experienced a global financial crisis, which many claim that only banks are at fault. Banks, as independent financial organizations, play the most important role in the financial market. Accordingly, banking has emerged and developed. This title, to put it briefly and clearly, covers the business of borrowing money and holding deposits. Over time, banking has undergone numerous transformations in the structure and types of business activities it covers. The banking sector today has stood out in the financial market as a separate sub-unit in the large financial system. Nevertheless, banks are still financial institutions, making it indisputable whether or not banks are a part of this system.

Analyzing the financial market, as a totality of financial institutions and the multiplicity of their procedures through which buyers and sellers of financial instruments are connected, a new term was found, namely, financial intervention or intermediation. Intermediation means collecting funds from the public and channeling them into financial placements, in the form of deposits, insurance sales, deposit payments, deposits into transaction accounts and more. This is where the modern theory of financial intermediation emerges, which is far more explicit in its analysis of banking and non-banking financial institutions. The importance of non-banking financial institutions stems from their role in collecting savings, which they pass on to banks, representing loan specialists. The main point of the research is that financial globalization, as a complex set of processes and sub-processes, opened the way for internationalization and universalization, followed by mediation and disintermediation as well as the integration of financial institutions and intermediaries.

Since the hypothesis was oriented on the influence of financial globalization on the banking, after analyzing theory and secondary data, the conclusion which can be derived is that financial globalization affects the rapid development of banking and reveals the great influence of the banking sector on other institutions. 


\title{
RAZVOJ BANKARSTVA U OKVIRU FINANCIJSKE GLOBALIZACIJE
}

\author{
Dino Bruža, mag. oec., prof. \\ Sveučilište Josipa Jurja Strossmayera u Osijeku, Ekonomski fakultet u Osijeku \\ Adresa: Trg Ljudevita Gaja 7, Osijek \\ e-mail:dino.bruza@gmail.com \\ Luka Latkovich, MSc \\ United Airline U.S.A. \\ Adresa: 42 Van Wagenen Avenue, apt. 12, Jersey City, NJ \\ e-mail: latkovich.luka@gmail.com
}

\section{SAŽETAK}

Banka ima svoju dugu povijest nastanka, ali u odnosu na to kratku prošlost kakvu je svijet poznaje danas. Prvi tragovi bankarstva se mogu povijesno smjestiti $u$ doba kada se novac polagao na čuvanje kod zlatara, ali tijekom vremena se razvila praksa pozajmljivanja viškova novca, zbog čega se mijenja i njezin koncept poslovanja. Predmet ovog istraživanja jest banka, kao dioničko društvo. Otkrivaju se odgovori vezani za pitanja o funkcioniranju banaka i bankarstva, objašnjavaju se odnosi banke i ostalih financijskih institucija, financijskog i bankarskog sustava te se iznosi uloga i značenje nebankarskih financijskih posrednika. Surha rada jest ukazati na ulogu i značaj banaka u poslovanju $i$ otkriti stupanj utjecaja na druge institucije. Elaborirajući izneseno, naglašava se ekonomski značaj u financijskoj globalizaciji. Cilj rada jest objasniti proces transformacije bankarskih usluga u globalnom okviru i poduzetništvu. Formirana je istraživačka hipoteza: financijska globalizacija utječe na brži razvoj bankarstva i na veći utjecaj bankarskog sektora na druge institucije. Tijekom istraživanja korišteno je nekoliko osnovnih znanstvenih metoda (metoda kompilacije, metoda deskripcije, metoda specifikacije i generalizacije te metoda usporedbe). Naglasak je stavljen na usporedbu uloge i značaja bankarskog sektora u prošlosti i u suvremenom poslovnom svijetu. Analizom razvoja bankarstva i poduzetništva se formira kvalitetan okvir za daljnje istraživanje, a dodana vrijednost čitatelju u pogledu boljeg razumijevanja razlike među financijskim institucijama, čemu doprinose i izdvojeni praktični primjeri odabranih globalnih banaka na globalnom tržištu.

Ključne riječi: banka; bankarski sustav; financijske operacije; financijska globalizacija; poduzetništvo 


\section{REFERENCES}

1. Battilossi, S. \& Reis, J. (2016). State and Financial Systems in Europe and the USA. London: Routledge.

2. Bazdan, Z. (2006). Recent trends in financial markets. Tourism and Hospitality Management, vol. 12, Opatija, Croatia, $89-101$.

3. Božina, M. (2003). Legal and Economic Aspects of Regulation of Commercial Banks in the Process of Economic and Monetary Integration of the Republic of Croatia. Zagreb: Faculty of Economics and Business.

4. Čečuk, A. (2002). Financial Globalization. Split: Graf form.

5. Gregurek, M., \& Vidaković, N. (2011). Bank business. Zagreb: RRiF.

6. Horne, J. C. \& Wachovicz, J. M. Jr. (2002). Fundamentals of Financial Management. Zagreb: MATE.

7. Huljak, I. (2015). Cost efficiency of banks in Croatia. Croatian Review of Economic, Business and Social Statistics, 1(1-2), 12 - 26. doi: https://doi.org/10.1515/crebss-2016-0002.

8. Institute for Local Self-Reliance (2019). Number of New Banks, 1993-2018, Preuzeto s https:// ilsr.org/number-of-new-banks-created-by-year-1993-to-2013/

9. Kandžija, V. \& Živko, I. (2004). Business Policy of Banks. Mostar \& Rijeka: Faculty of Economics, University of Mostar, Faculty of Economics and Business, University of Rijeka.

10. LeRoy, R., et al. (1997). Modern Money and Banking. Zagreb: MATE.

11. Mishkin, F. S. (2010). The Economics of Money, Banking and Financial Markets. Zagreb: MATE.

12. Mishkin, F. S. \& Eakins, S. G., (2005). Financial Markets and Institutions. Zagreb: MATE.

13. Saunders, A. \& Cornett, M. M. (2006). Financial Markets and Institutions. Zagreb: MASMEDIA.

14. Statista. (2020). Leading banks in Europe 2019, by total assets, analysis, https://www.statista. com/statistics.

15. Šverko, I. (2002). Risk Value as a Method of Risk Management in Financial Institutions - Economic Review, Zagreb: Faculty of Economics.

16. Yaron, J. \& Schreiner, M. (2001). Development Finance Institutions: Measuring their Subsidy. Washington D.C.: The International Bank for Reconstruction and Development. 